\title{
Hepatoprotective activity of Sonchus asper against carbon tetrachloride-induced injuries in male rats: a randomized controlled trial
}

\author{
Rahmat A Khan ${ }^{1,2^{*} \dagger}$, Muhammad R Khan ${ }^{2 \dagger}$, Sumaira Sahreen ${ }^{2,3 \dagger}$ and Naseer Ali Shah ${ }^{2 \dagger}$
}

\begin{abstract}
Background: Sonchus asper (SAME) is used as a folk medicine in hepatic disorders. In this study, the hepatoprotective effects of the methanol extract of SAME was evaluated against carbon tetrachloride $\left(\mathrm{CCl}_{4}\right)$-induced liver injuries in rats.

Methods: To evaluate the hepatoprotective effects of SAME, 36 male Sprague-Dawley rats were equally divided into 6 groups. Rats of Group I (control) were given free access to approved feed and water. Rats of Group II were injected intraperitoneally with $\mathrm{CCl}_{4}(3 \mathrm{ml} / \mathrm{kg})$ as a $30 \%$ solution in olive oil $(\mathrm{v} / \mathrm{v})$ twice a week for 4 weeks. Animals of Groups III $(100 \mathrm{mg} / \mathrm{kg})$ and IV (200 mg/kg) received SAME, whereas those of Group V were given silymarin via gavage (100 mg/ $\mathrm{kg})$ after $48 \mathrm{~h}$ of $\mathrm{CCl}_{4}$ treatment. Group VI received SAME $(200 \mathrm{mg} / \mathrm{kg})$ twice a week for 4 weeks without $\mathrm{CCl}_{4}$ treatment. Various parameters, such as the serum enzyme levels, serum biochemical marker levels, antioxidant enzyme activities, and liver histopathology were used to estimate the hepatoprotective efficacy of SAME.
\end{abstract}

Results: The administration of SAME and silymarin significantly lowered the $\mathrm{CCl}_{4}$-induced serum levels of hepatic marker enzymes (aspartate aminotransferase, alanine aminotransferase, and lactate dehydrogenase), cholesterol, low-density lipoprotein, and triglycerides while elevating high-density lipoprotein levels. The hepatic contents of glutathione and activities of catalase, superoxide dismutase, glutathione peroxidase, glutathione S-transferase, and glutathione reductase were reduced. The levels of thiobarbituric acid-reactive substances that were increased by $\mathrm{CCl}_{4}$ were brought back to control levels by the administration of SAME and silymarin. Liver histopathology showed that SAME reduced the incidence of hepatic lesions induced by $\mathrm{CCl}_{4}$ in rats.

Conclusion: SAME may protect the liver against $\mathrm{CCl}_{4}$-induced oxidative damage in rats.

Keywords: Carbon tetrachloride, Sonchus asper, Liver histopathology, Antioxidant, Lipid peroxidation, Liver enzymes

\section{Background}

Hepatotoxicity is the most widespread pathology worldwide, representing up to $83 \%$ of all cases. Hepatitis, viral infections, food additives, alcohol, toxic industrial chemicals, and air and water pollutants are the major risk factors of liver toxicity. There is increasing evidence that free radicals and reactive oxygen species play a crucial role in various steps that initiate and regulate the progression of liver diseases independently of the original agent [1]. Carbon tetrachloride $\left(\mathrm{CCl}_{4}\right)$ is a potent

\footnotetext{
* Correspondence: Rahmatgul_81@yahoo.com

${ }^{\dagger}$ Equal contributors

'Department of Biotechnology, Faculty of Biological Sciences, University of Science and Technology Bannu, Khyber Pakhtunkhwa, Pakistan

${ }^{2}$ Department of Biochemistry, Faculty of Biological Sciences, Quaid-I-Azam University Islamabad, Islamabad, Pakistan

Full list of author information is available at the end of the article
}

environmental hepatotoxin [2] that, in addition to hepatic problems, causes dysfunction of the kidneys, lungs, testis, brain, and blood by generating free radicals $[3,4]$.

$\mathrm{CCl}_{4}$ requires bioactivation in phase I of the cytochrome $\mathrm{P} 450$ system to form the reactive metabolic trichloromethyl radical (. $\left.\mathrm{CCl}_{3}\right)$ and trichloromethyl peroxy radical $\left(. \mathrm{OOCCl}_{3}\right)$. These free radicals can bind with polyunsaturated fatty acids to produce alkoxy (R.) and peroxy radicals (ROO.) that, in turn, generate lipid peroxides that are highly reactive, change enzyme activity, and finally induce injury or necrosis with corresponding health problems $[5,6]$.

$\mathrm{CCl}_{4}$ is known to decrease glutathione (GSH) of phase II enzymes and reduce antioxidant enzymes and substrates to induce oxidative stress, which is an important factor in acute and chronic injuries in various tissues $[7,8]$. 
Free radicals of $\mathrm{CCl}_{4}$ reduce the $\mathrm{GSH}$ contents and activities of antioxidant enzymes, leading to hepatic injury [9]. The depletions of these antioxidant enzymes occur secondary to the controlling action against peroxy radicals produced by $\mathrm{CCl}_{4}$. Reactive oxygen species cause oxidative DNA damage in the form of DNA adducts, genetic mutation, strand breakage, and chromosomal alterations [10]. Some recent investigations revealed that free radicals increased the number of argyrophilic nucleolar organizer regions (AgNORs) and activity of telomerase in kidney tissues [11], caused depletion of cytochrome P450 2E1, and increased the 8-hydroxyl-2 deoxyguanosine concentration [12]. DNA fragmentation causes p53 gene expression, blocks the cell cycle, and gives additional time to repair DNA. However, severe DNA damage triggers apoptosis [13].

Sonchus asper (SAME), locally called Mahtari, is a common herb that grows wildly and abundantly in open fields. Chemical studies of SAME indicated a high content of vitamin C (ascorbic acid) [14], carotenoids, and type $\omega-3$ fatty acids $[15,16]$. Phenolic compounds, which are secondary metabolites in plants, are one of the most widely occurring groups of phytochemicals that exhibit a wide range of physiological properties, such as antioxidant, anti-allergenic, anti-microbial, anti-artherogenic, antithrombotic, anti-inflammatory, vasodilatory, and cardioprotective effects $[17,18]$. Chemical characterization of SAME has shown the presence of ionone derivatives of glycosides and sesquiterpene lactone glycosides [19]. These bioactive compounds have been shown to possess strong antioxidant and anti-inflammatory properties [20]. SAME has diuretic, refrigerant, sedative, and antiseptic properties that are used in the treatment of cough, bronchitis, and asthma [21] as well as kidney inflammation [22], and its decoction is used in the treatment of impotence (erectile dysfunction) [23]. With increasing recognition of herbal medicine and phytotherapy as alternative forms of health care, the objectives of this study were to evaluate the antioxidant and hepatoprotective properties of SAME against $\mathrm{CCl}_{4}$-induced hepatic injuries in Sprague-Dawley male rats.

\section{Methods}

\section{Chemicals}

Reduced glutathione (GSH), oxidized glutathione (GSSG), glutathione reductase, gamma-glutamyl p-nitroanilide, glycylglycine, bovine serum albumin (BSA), 1,2-dithio-bis nitro benzoic acid (DTNB), 1-chloro-2,4-dinitrobenzene (CDNB), reduced nicotinamide adenine dinucleotide phosphate (NADPH), $\mathrm{CCl}_{4}$, flavine adenine dinucleotide (FAD), glucose-6-phosphate, Tween-20, 2,6-dichlorophenolindophenol, thiobarbituric acid (TBA), picric acid, sodium tungstate, sodium hydroxide, trichloroacetic acid (TCA) and perchloric acid (PCA) were purchased from Sigma Chemicals Co. USA.

\section{Plant collection}

Plants of Sonchus asper at maturity were collected from Wah Cantt, District Rawalpindi (Pakistan) during June, 2010. Plants were identified by Prof. Dr. Mir Ajab Khan (Dean Faculty of Biological Sciences, Quaid-i-Azam University Islamabad, Pakistan) and a specimen was submitted vide \#147 at Herbarium of Pakistan (Quaid-i-Azam University Islamabad, Pakistan). Whole plant (leaves, stem, flowers, roots and seeds) were shades dried at room temperature for two weeks, chopped, ground mechanically of $1 \mathrm{~mm}$ mesh size.

\section{Preparation of plant extracts}

Five kg powder of Sonchus asper was socked in 10 liters of methanol with shaking a number of times. After a week of socking the extract was filtered through Whatmann filter paper \# 45, and the filtrate was evaporated through rotary vacuum evaporator to get $407 \mathrm{~g}$ of methanol crude extract (SAME), stored at $4^{\circ} \mathrm{C}$ until further use.

\section{Animals}

Six week old, 36 Sprague Dawley male rats (190-200 g) were provided by National Institute of Health Islamabad and were kept in ordinary cages at room temperature of $25 \pm 3^{\circ} \mathrm{C}$ with a $12 \mathrm{~h}$ dark/light cycle. They were allowed to standard laboratory feed and water. The study protocol was approved by Ethical Committee of Quaid-i-Azam University Islamabad for laboratory animal feed and care.

\section{Experimental design}

To study the antioxidant effects of SAME, rats were equally divided into 6 groups (6 rats). Group 1 received only vehicles olive oil; $(1 \mathrm{ml} / \mathrm{kg}$ bw) and DMSO $(1 \mathrm{ml} / \mathrm{kg}$ bw) and have free access to food materials. Animals of group II, III and IV received $\mathrm{CCl}_{4} 3 \mathrm{ml} / \mathrm{kg}$ (30\% in olive oil; v/v) intraperitoneally twice a week for four weeks. Group II was treated with $\mathrm{CCl}_{4}$ only while group III (100 mg/kg bw) and IV received (200 mg/kg bw) SAME (intragastric, in DMSO) after $48 \mathrm{~h}$ of $\mathrm{CCl}_{4}$. Rats of group $\mathrm{V}$ were given silymarin (intragastric, in DMSO) at a dose of $100 \mathrm{mg} / \mathrm{kg}$ bw, after $48 \mathrm{~h}$ of $\mathrm{CCl}_{4}$ treatment. Animals of a group VI were given SAME $(200 \mathrm{mg} / \mathrm{kg} \mathrm{bw})$ intragastrically. Experimental period was of four weeks. After $24 \mathrm{~h}$ of the last treatment, all the animals were weighted, sacrificed; collected their blood, weighted and perfuse a liver in ice-cold saline solution. Half of liver tissues was treated with liquid nitrogen for further enzymatic and DNA damage analysis while the other portion was processed for histology.

\section{Assessment of serum markers}

Serum analysis of various liver marker enzymes such as alanine aminotransferase (ALT), aspartate aminotransferase (AST), alkaline phosphatase (ALP), lactate dehydrogenase 
(LDH) and biochemical markers; level of total cholesterol (TC), high-density lipoproteins (HDL), low-density lipoproteins (LDL) and triglycerides (TG) were estimated by using standard AMP diagnostic kits (Stattogger Strasse 31b 8045 Graz, Austria).

\section{Assessment of antioxidant status}

$70 \mathrm{mg}$ of liver tissue was homogenized in 10 volumes of $100 \mathrm{mmol} \mathrm{KH}_{2} \mathrm{PO}_{4}$ buffer containing $1 \mathrm{mmol}$ EDTA $\left(\mathrm{pH} 7.4\right.$ ) and centrifuged at $12,000 \times \mathrm{g}$ for $30 \mathrm{~min}$ at $4{ }^{\circ} \mathrm{C}$. The supernatant was collected and used for determination of antioxidant status as described below using concentration of protein estimated following the method of Lowry et al. [24]. Antioxidant status, including activity of catalase [25], superoxide dismutase [26], glutathioneS-transferase assay [27], glutathione reductase [28], glutathione peroxidase [29], reduced glutathione assay [30] and lipid peroxidation assay [31] were performed on various hepatic samples.

\section{DNA fragmentation\% assay}

DNA fragmentation assay was conducted using the procedure of $\mathrm{Wu}$ et al. [32] with some modifications. The liver tissue (50 mg) was homogenized in 10 volumes of a TE solution $\mathrm{pH} 8.0$ (5 mmol Tris- $\mathrm{HCl}, 20 \mathrm{mmol}$ EDTA) and $0.2 \%$ triton $\mathrm{X}-100.1 .0 \mathrm{ml}$ aliquot of each sample was centrifuged at $27,000 \times \mathrm{g}$ for $20 \mathrm{~min}$ to separate the intact chromatin (pellet, B) from the fragmented DNA (supernatant, T). The pellet and supernatant fractions were assayed for DNA content using a freshly prepared DPA (Diphenylamine) solution for reaction. Optical density was read at $620 \mathrm{~nm}$ with (SmartSpecTM Plus Spectrophotometer catalog \# 170-2525) spectrophotometer. The results were expressed as an amount of \% fragmented DNA by the following formula;

$\%$ Fragmented DNA $=\mathrm{T} \times 100 /(\mathrm{T}+\mathrm{B})$

\section{AgNORs count}

Silver staining technique was used according to the Trere et al. [33]. The AgNORs technique was performed on dried slides as follows; unstained fixed slides were dewaxed by dipping for 3 minutes in xylene. After complete removal of wax, the slides were hydrated in decreasing ethanol concentration (90, 70 and 50\%) and washed in distilled water for $10 \mathrm{~min}$ and dried in an oven. After drying slides were treated with one drop of colloidal solution ( $2 \%$ gelatin and $1 \%$ formic acid) and two drops of $50 \% \mathrm{AgNO}_{3}$ solution on the slide and incubated at $35^{\circ} \mathrm{C}$ for about $8-12 \mathrm{~min}$. The progressive staining was followed under a microscope to get golden colored nuclei and brown/black NORs. Then, the slide was washed in distilled water, treated for $1 \mathrm{~min}$ with $1 \%$ sodium thiosulphate at room temperature to stop the reaction, and washed in tap water. The cells were examined under a light microscope at $100 \times$ magnifications and number of AgNORs was counted per cell.

\section{Histopathological studies}

For microscopic evaluation, liver were fixed in a fixative (absolute ethanol 60\%, formaldehyde 30\%, and glacial acetic acid 10\%) and embedded in paraffin, sectioned at $4 \mu \mathrm{m}$ and subsequently stained with hematoxylin/eosin. Sections were studied under a light microscope (DIALUX $20 \mathrm{~EB})$ at 40 and 100 magnifications. Slides of all the treated groups were studied and photographed.

\section{Statistical analysis}

Data were expressed as mean and standard error (SE) and ANOVA test were used to analyze the difference among various treatments, with least significance difference (LSD) at 0.05 and 0.01 as a level of significance. SPSS ver. 14.0 (Chicago, IL, USA) and Microsoft Excel 2007 (Roselle, IL, USA) were used for the statistical and graphical evaluations.

Table 1 Effect of SAME on liver function test in rat

\begin{tabular}{|c|c|c|c|c|}
\hline Treatment & $\begin{array}{l}\text { ALT } \\
(\mathrm{U} / \mathrm{L})\end{array}$ & $\begin{array}{l}\text { AST } \\
\text { (U/L) }\end{array}$ & $\begin{array}{l}\text { ALP } \\
(U / L)\end{array}$ & $\begin{array}{l}\mathrm{LDH}(\mathrm{nmol} / \mathrm{min} / \\
\mathrm{mg} \text { protein) }\end{array}$ \\
\hline Control & $52 . \pm 2.12++$ & $76 \pm 2.74++$ & $198 \pm 3.93++$ & $48.3 \pm 2.38++$ \\
\hline $3 \mathrm{ml} / \mathrm{kg} \mathrm{CCl} 4$ & $111 \pm 3.42^{* *}$ & $234.0 \pm 4.27^{* *}$ & $470.3 \pm 6.49^{* *}$ & $77.6 \pm 2.46^{* *}$ \\
\hline $100 \mathrm{mg} / \mathrm{kg} \mathrm{SAME}+\mathrm{CCl}_{4}$ & $91 \pm 3.23^{* *}++$ & $136 \pm 4.91^{* *}++$ & $347.7 \pm 10.7^{* *}++$ & $66 \pm 3.76^{* *}+$ \\
\hline $200 \mathrm{mg} / \mathrm{kg} \mathrm{SAME}+\mathrm{CCl}_{4}$ & $56 \pm 1.35++$ & $97.5 \pm 2.90^{* *}++$ & $217.8 \pm 3.91^{*}++$ & $53 \pm 2.61++$ \\
\hline 100 mg/kg Silymarin $+\mathrm{CCl}_{4}$ & $58 \pm 2.68++$ & $102.3 \pm 4.99^{* *}++$ & $227.5 \pm 3.89^{* *}++$ & $50 \pm 4.08++$ \\
\hline 200 mg/kg SAME alone & $50 \pm 2.14++$ & $75.5 \pm 3.26++$ & $195.3 \pm 4.11++$ & $46 \pm 2.38++$ \\
\hline
\end{tabular}

Mean $\pm S E$ ( $n=6$ number).

** Significance from the control group at $P<0.01$ probability level.

++ Significance from the $\mathrm{CCl}_{4}$ group at $P<0.01$ probability level. 
Table 2 Effect SAME on serum level of biochemical markers in rat

\begin{tabular}{|c|c|c|c|c|}
\hline Treatment & $\begin{array}{l}\text { Triglycerides } \\
\text { (mg/dl) }\end{array}$ & $\begin{array}{l}\text { Total cholesterol } \\
\text { (mg/dl) }\end{array}$ & $\begin{array}{l}\mathrm{HDL} \\
(\mathrm{mg} / \mathrm{dl})\end{array}$ & $\begin{array}{l}\text { LDL } \\
(\mathrm{mg} / \mathrm{dl})\end{array}$ \\
\hline Control & $7.8 \pm 0.45++$ & $6.1 \pm 0.25++$ & $3.6 \pm 0.21++$ & $2.48 \pm 0.32++$ \\
\hline $3 \mathrm{ml} / \mathrm{kg} \mathrm{CCl}_{4}$ & $11.3 \pm 0.58^{* *}$ & $11.2 \pm 0.23^{* *}$ & $2.8 \pm 0.18^{* *}$ & $8.4 \pm 0.17^{* *}$ \\
\hline $100 \mathrm{mg} / \mathrm{kg} \mathrm{SAME}+\mathrm{CCl}_{4}$ & $9.2 \pm 0.41^{* *}++$ & $7.7 \pm 0.21^{* *}++$ & $3.08 \pm 0.09^{* *}++$ & $4.2 \pm 0.21^{* *}++$ \\
\hline $200 \mathrm{mg} / \mathrm{kg} \mathrm{SAME}+\mathrm{CCl}_{4}$ & $8.3 \pm 0.18++$ & $6.4 \pm 0.27++$ & $3.5 \pm 0.20++$ & $2.53 \pm 0.35++$ \\
\hline $100 \mathrm{mg} / \mathrm{kg}$ Silymarin $+\mathrm{CCl}_{4}$ & $7.2 \pm 0.44++$ & $5.7 \pm 0.19++$ & $3.7 \pm 0.21++$ & $2.21 \pm 0.31++$ \\
\hline 200 mg/kg SAME alone & $7.5 \pm 0.44++$ & $5.8 \pm 0.44++$ & $3.75 \pm 0.21++$ & $2.36 \pm 0.12++$ \\
\hline
\end{tabular}

Mean \pm SE ( $n=6$ number).

** Significance from the control group at $P<0.01$ probability level.

++ Significance from the $\mathrm{CCl}_{4}$ group at $P<0.01$ probability level.

\section{Results}

Effect of SAME on alanine aminotransferase, aspartate aminotransferase, alkaline phosphatase, and lactate

\section{dehydrogenase}

The levels of certain serum marker enzymes, including alanine aminotransferase (ALT), aspartate aminotransferase (AST), alkaline phosphatase (ALP), and lactate dehydrogenase (LDH), are highly susceptible to hepatotoxins. They serve as markers of liver damage and oxidative stress, which promote the release of aminotransferases from hepatocytes into the bloodstream. The protective effects of SAME and silymarin on the activity of liver serum marker enzymes are shown in Table 1. Administration of $\mathrm{CCl}_{4}$ to rats significantly $(\mathrm{P}<0.01)$ increased the activity of liver serum marker enzymes compared with controls. The levels of ALT, AST, ALP, and LDH were significantly $(\mathrm{P}<0.01)$ and dosedependently restored by treatment with SAME and silymarin compared with the $\mathrm{CCl}_{4}$ group. However, nonsignificant variation was observed by SAME treatment alone compared with the control group.

Effect of SAME on triglycerides, total cholesterol, highdensity lipoprotein, and low-density lipoprotein

The effect of SAME on the cholesterol profile is shown in Table 2. Administration of $\mathrm{CCl}_{4}$ significantly
$(\mathrm{P}<0.01)$ increased the concentration of triglycerides, total cholesterol, and low-density lipoprotein, but decreased the high-density lipoprotein level compared with the control group. The $\mathrm{CCl}_{4}$-induced alteration of the cholesterol profile was significantly $(\mathrm{P}<0.01)$ restored with SAME treatment at both doses (100 $\mathrm{mg} / \mathrm{kg}$ and $200 \mathrm{mg} / \mathrm{kg}$ ) compared with the control group. Silymarin resulted in a degree of recovery of the cholesterol profile comparative with that achieved with the high dose of SAME.

\section{Effect of SAME on antioxidant and lipid peroxidation enzymes in liver}

The toxicity of $\mathrm{CCl}_{4}$ significantly decreased the liver catalase, superoxide dismutase, GSH S-transferase, GSH peroxidase (GSH-Px), and GSH reductase levels of the control group (Table 3). Addition of SAME at doses of 100 and $200 \mathrm{mg} / \mathrm{kg}$ and silymarin at 100 $\mathrm{mg} / \mathrm{kg}$ reversed the decreased hepatic catalase and superoxide dismutase levels. In particular, the high dose of SAME $(200 \mathrm{mg} / \mathrm{kg})$ almost completely restored the catalase and superoxide dismutase activities to the control levels. The hepatic levels of GSH $\mathrm{S}$-transferase, GSH-Px, and GSH reductase were partially reversed by SAME at $200 \mathrm{mg} / \mathrm{kg}$.

Table 3 Effect of SAME on antioxidant defense system in rat liver

\begin{tabular}{|c|c|c|c|c|c|}
\hline Treatment & $\begin{array}{l}\text { CAT } \\
\text { (U/min) }\end{array}$ & $\begin{array}{l}\text { SOD } \\
\text { (U/mg protein) }\end{array}$ & $\begin{array}{l}\text { GST } \\
\mathrm{nmol} / \mathrm{min} / \mathrm{mg} \text { protein }\end{array}$ & $\begin{array}{l}\mathrm{GR} \\
\mathrm{nmol} / \mathrm{min} / \mathrm{mg} \text { protein }\end{array}$ & $\begin{array}{l}\text { GSH-Px } \\
\mathrm{nmol} / \mathrm{min} / \mathrm{mg} \text { protein }\end{array}$ \\
\hline Control & $4.8 \pm 0.10++$ & $22.7 \pm 1.18++$ & $192 \pm 2.49++$ & $127.3 \pm 10.5++$ & $84.2 \pm 5.9++$ \\
\hline $3 \mathrm{ml} / \mathrm{kg} \mathrm{CCl} 4$ & $2.9 \pm 0.06^{* *}$ & $11.9 \pm 0.38^{* *}$ & $104 \pm 2.4^{* *}$ & $62.33 \pm 9.28^{* *}$ & $46 \pm 3.6^{* *}$ \\
\hline $100 \mathrm{mg} / \mathrm{kg} \mathrm{SAME}+\mathrm{CCl}_{4}$ & $4.04 \pm 0.09++$ & $16.2 \pm 0.38^{*}++$ & $142 \pm 2.6^{*}++$ & $90.2 \pm 11.3^{*}++$ & $61 \pm 6.6^{*}++$ \\
\hline $200 \mathrm{mg} / \mathrm{kg} \mathrm{SAME}+\mathrm{CCl}_{4}$ & $4.8 \pm 0.125++$ & $20.4 \pm 0.37++$ & $190 \pm 2.9++$ & $112.3 \pm 6.5++$ & $75 \pm 4.2++$ \\
\hline $100 \mathrm{mg} / \mathrm{kg}$ Silymarin $+\mathrm{CCl}_{4}$ & $4.9 \pm 0.116++$ & $22.9 \pm 0.57++$ & $201 \pm 2.5++$ & $134.3 \pm 5.7++$ & $84 \pm 4.0++$ \\
\hline 200 mg/kg SAME alone & $4.96 \pm 0.05++$ & $24.7 \pm 0.38++$ & $199 \pm 2.19++$ & $132.3 \pm 6.96++$ & $87 \pm 3.5++$ \\
\hline
\end{tabular}

Mean \pm SE ( $n=6$ number).

* ** Significance from the control group at $P<0.05$ and $P<0.01$ probability level.

++ Significance from the $\mathrm{CCl}_{4}$ group at $P<0.01$ probability level. 
Table 4 Effect SAME on TBARS and GSH contents in rat liver

\begin{tabular}{lll}
\hline Treatment & GSH $(\boldsymbol{\mu m o l} / \mathbf{g}$ tissue) & $\begin{array}{l}\text { TBARS }(\mathbf{n m o l} / \mathbf{m i n} \\
\text { /mg protein) }\end{array}$ \\
\hline Control & $1.23 \pm 0.02++$ & $28.33 \pm 1.12++$ \\
$3 \mathrm{ml} / \mathrm{kg} \mathrm{CCl}$ & $52.17 \pm 2.61^{* *}$ \\
$100 \mathrm{mg} / \mathrm{kg} \mathrm{SAME}+\mathrm{CCl}_{4}$ & $1.09 \pm 0.02^{* *}++$ & $43.0 \pm 2.76^{* *}++$ \\
$200 \mathrm{mg} / \mathrm{kg} \mathrm{SAME}+\mathrm{CCl}_{4}$ & $1.81 \pm 0.50++$ & $30.0 \pm 1.77++$ \\
$100 \mathrm{mg} / \mathrm{kg} \mathrm{Silymarin}+\mathrm{CCl}_{4}$ & $1.27 \pm 0.013++$ & $27.17 \pm 1.22++$ \\
$200 \mathrm{mg} / \mathrm{kg} \mathrm{SAME}$ alone & $1.25 \pm 0.018++$ & $27.50 \pm 1.82++$ \\
\hline
\end{tabular}

Mean \pm SE ( $n=6$ number).

** Significance from the control group at $P<0.01$ probability level.

++ Significance from the $\mathrm{CCl}_{4}$ group at $P<0.01$ probability level.

\section{Effect of SAME on GSH and thiobarbituric acid-reactive} substances in liver

The hepatic level of GSH was decreased while the thiobarbituric acid-reactive substances (TBARS) were increased in the $\mathrm{CCl}_{4}$-treated animals compared with the controls (Table 4 ). The $\mathrm{CCl}_{4}$-induced changes in these parameters were dose-dependently diminished by oral addition of various doses of SAME and silymarin. No significant changes in GSH or TBARS were found with SAME alone compared with control rats.

Effect of SAME on body weight, absolute liver weight, relative liver weight, \% DNA fragmentation, and AgNORs in rat liver

The NORs stained by silver ion and the AgNORassociated proteins, called AgNOR proteins, play a significant role in differentiation of tumor cells from normal cells, as shown along with increases in liver weight, relative liver weight, \% DNA fragmentation, and \% increases in body weight (Table 5). Administration of $\mathrm{CCl}_{4}$ significantly $(\mathrm{P}<0.01)$ amplified the number of NORs per cell, increased the liver weight, increased the relative liver weight, increased the \% DNA fragmentation, and decreased the \% increase in body weight compared with untreated rats. However, $50 \mathrm{mg} / \mathrm{kg}$ of silymarin and various doses of SAME augmented the $\mathrm{CCl}_{4}$-induced intoxication and significantly $(\mathrm{P}<0.01)$ recovered the NORs per cell, body weight, liver weight, and relative liver weight. The \% DNA fragmentation was markedly $(\mathrm{P}<0.01)$ decreased.

\section{Effect of SAME on liver histology}

Histopathological investigation results showed significant correlations with the biochemical study results. The graded observations of hematoxylin and eosin-stained sections are shown in Table 6 and Figure 1. Administration of $\mathrm{CCl}_{4}$ caused marked increases in fatty changes and cellular hypertrophy; cellular aggregation caused benign tumor formation, and inflammatory cell infiltration, ballooning, and congestion of blood vessels were observed compared with controls. Administration of SAME attenuated the hepatic injuries with little or no fatty changes; dilation of blood vessels and uniform hepatocyte morphology nearly identical to that of the control group was found. Similar observations were recorded after silymarin treatment. These results suggest a positive correlation of SAME and silymarin with the activities of serum aminotransferases and hepatic lipid peroxidation and hepatic antioxidant enzymes.

\section{Discussion}

A number of drugs, toxic industrial chemicals, and viral infections have been reported to cause severe hepatic injuries, which are sometimes difficult to manage by medical therapies. It is important to evaluate plant extracts that can be used for improved treatment of hepatic failure caused by severe oxidative stress and necrosis [34]. Estimation of serum enzymes is a useful quantitative marker of the extent and type of hepatocellular damage. Increases in serum AST, ALT, ALP, and LDH levels have been attributed to damaged structural integrity of the liver, because these are cytoplasmic in location and are released into the circulation after autolytic breakdown or cellular necrosis

Table 5 Effect of SAME on absolute liver weight, relative liver weight, and \% DNA fragmentation and AgNORs in rat liver

\begin{tabular}{llllll}
\hline Treatment & $\begin{array}{l}\text { \% increase } \\
\text { inbody weight }\end{array}$ & $\begin{array}{l}\text { Absolute liver } \\
\text { weight } \mathbf{( g )}\end{array}$ & $\begin{array}{l}\text { Relative liver weight } \\
\text { (\% to body weight) }\end{array}$ & $\begin{array}{l}\text { AgNORs } \\
\text { (NORs/cell) }\end{array}$ & $\begin{array}{l}\text { \%DNA } \\
\text { fragmentation }\end{array}$ \\
\hline Control & $35.00 \pm 0.87++$ & $7.0 \pm 0.23++$ & $0.07 \pm 0.002++$ & $2.0 \pm 0.33++$ & $5.33 \pm 2.46++$ \\
$3 \mathrm{ml} / \mathrm{kg} \mathrm{CCl}$ & $24.52 \pm 0.92^{* *}$ & $8.6 \pm .89^{* *}$ & $0.86 \pm .0016^{* *}$ & $6.4 \pm .29^{* *}$ & $22.50 \pm 3.68^{* *}$ \\
$100 \mathrm{mg} / \mathrm{kg} \mathrm{SAME}+\mathrm{CCl}_{4}$ & $30.08 \pm 0.81^{* *++}$ & $7.4 \pm 0.10^{*++}$ & $0.074 \pm 0.001^{*++}$ & $3.5 \pm 0.18^{* *++}$ & $6.67 \pm 2.08++$ \\
$200 \mathrm{mg} / \mathrm{kg} \mathrm{SAME}+\mathrm{CCl}_{4}$ & $35.64 \pm 0.73++$ & $7.04 \pm 0.23++$ & $0.070 \pm 0.0023++$ & $2.14 \pm 0.23++$ & $5.67 \pm 3.12++$ \\
$100 \mathrm{mg} / \mathrm{kg} \mathrm{Silymarin}+\mathrm{CCl}_{4}$ & $36.82 \pm 0.69++$ & $6.83 \pm 0.07++$ & $0.068 \pm 0.007++$ & $1.9 \pm 0.17^{* *++}$ & $4.67 \pm 2.23++$ \\
$200 \mathrm{mg} / \mathrm{kg} \mathrm{SAME}$ alone & $35.72 \pm 0.70++$ & $6.8 \pm 0.12++$ & $0.068 \pm 0.011++$ & $1.96 \pm 0.12++$ & $5.50 \pm 3.2++$ \\
\hline
\end{tabular}

Mean \pm SE ( $n=6$ number).

* ** Significance from the control group at $P<0.05$ and $P<0.01$ probability level.

++ Significance from the $\mathrm{CCl}_{4}$ group at $P<0.01$ probability level. 
Table 6 Effects of SAME on histology of liver

\begin{tabular}{lllll}
\hline Treatment & Fatty changes & $\begin{array}{l}\text { Cellular aggregation } \\
\text { hypertrophy }\end{array}$ & $\begin{array}{l}\text { Blood vessel } \\
\text { congestion }\end{array}$ & $\begin{array}{l}\text { Inflammatory cells } \\
\text { infiltrations }\end{array}$ \\
\hline Control & - & - & - & - \\
$3 \mathrm{ml} / \mathrm{kg} \mathrm{CCl} 4$ & +++ & ++ & ++ & +++ \\
$100 \mathrm{mg} / \mathrm{kg} \mathrm{SAME}+\mathrm{CCl}_{4}$ & - & $-/+$ & - & $-/+$ \\
$200 \mathrm{mg} / \mathrm{kg} \mathrm{SAME}+\mathrm{CCl}_{4}$ & - & - & - & - \\
$100 \mathrm{mg} / \mathrm{kg} \mathrm{Silymarin}+\mathrm{CCl}_{4}$ & - & - & - & - \\
$200 \mathrm{mg} / \mathrm{kg} \mathrm{SAME}$ alone & - & - & - & - \\
\hline
\end{tabular}

-, normal; +/-, mild; ++, medium; +++, severe disruption.

[35]. Therefore, marked release of AST, ALT, ALP, and LDH into the circulation indicates severe damage to hepatic tissue membranes during $\mathrm{CCl}_{4}$ intoxication [36]. The reversal of increased serum enzymes in $\mathrm{CCl}_{4}$-induced liver damage by SAME may occur secondary to prevention of leakage of intracellular enzymes by the membrane stabilization and antioxidant activity of SAME; this was supported by the histological results in the present study. Thus, the anti-lipid peroxidation and/or adaptive nature of the systems brought about by SAME acted against the damaging effects of free radicals produced by $\mathrm{CCl}_{4}$. Similar hepatoprotective effects have been described for S. arvensis [37]. High levels of serum cholesterol, low-density lipoprotein, and triglycerides and lower concentrations of highdensity lipoprotein were induced with $\mathrm{CCl}_{4}$ in rats, consistent with results of other studies [36,38,39].
Catalase, superoxide dismutase, and GSH-Px constitute a "mutually supportive team" of antioxidant defenses and play a key role in detoxification of free radicals [40,41]. Administration of $\mathrm{CCl}_{4}$ into rat livers increased lipid peroxidation, resulting in accumulation of superoxide radicals and consequently decreased their activities in the liver [42]. Our data revealed that $\mathrm{CCl}_{4}$ treatment significantly decreased the activities of catalase, superoxide dis mutase, GSH-Px, and GSH reductase in liver tissues. Co-administration of SAME markedly decreased the toxicity of $\mathrm{CCl}_{4}$ and enzymatic activities. Ameliorating effects of different plant metabolites on these enzymes against the toxicity of $\mathrm{CCl}_{4}$ have also been documented [42]. TBARS is a major reactive aldehyde resulting from the peroxidation of polyunsaturated fatty acids. It is a useful indicator of tissue damage, including a series of chain reactions [43]. High hepatic levels

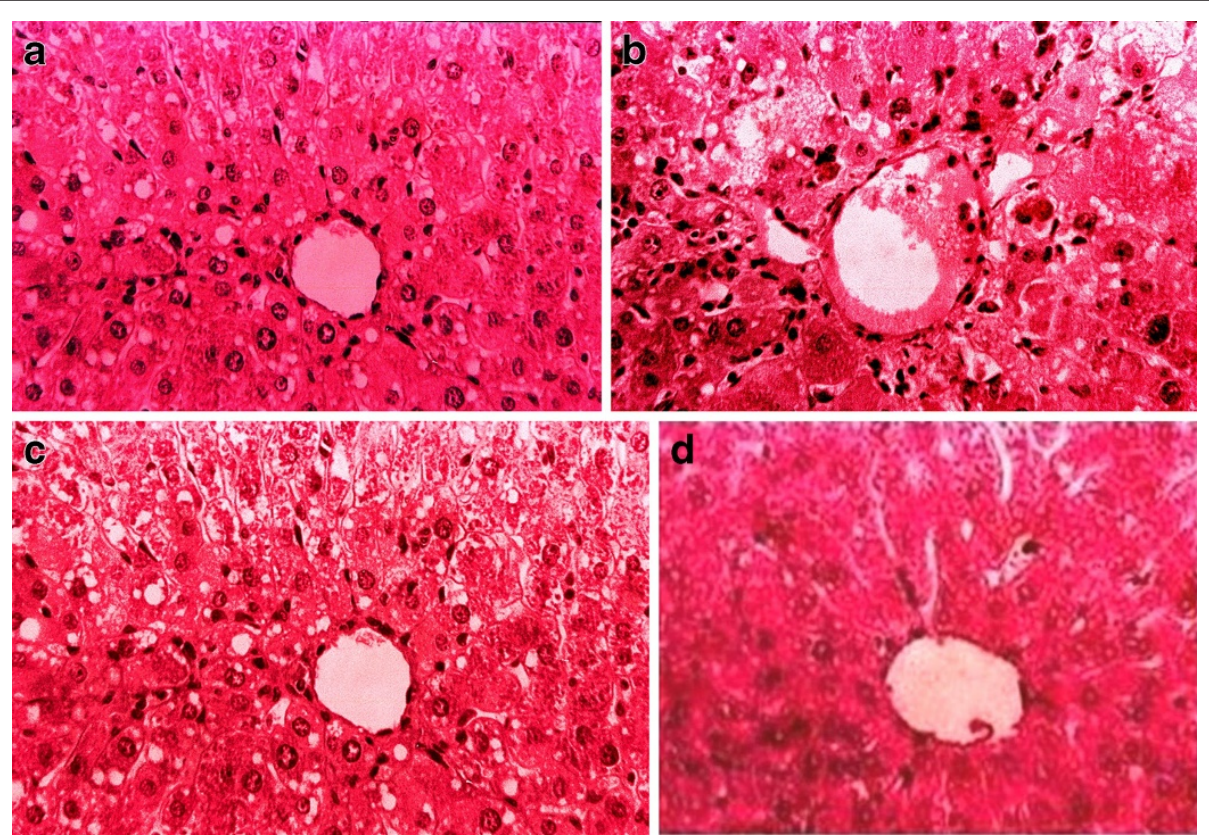

Figure 1 (a) Hemotoxylin and Eosin-stained liver section of control rat (b) Liver section of $\mathrm{CCl}_{4}$ treated rats showing marked fatty changes, cellular hypertrophy, degeneration of the lobular architecture and blood vessel congestion with disturbed epithelium (c) Liver section of $\mathrm{CCl}_{4}+\mathrm{SAME}$ showing less injuries (d) Liver section of $\mathrm{CCl}_{4}+$ Silymarin showing less injuries. 
of TBARS and nitrite with $\mathrm{CCl}_{4}$ treatment indicate extensive oxidative damage to liver tissues. Restoration of nitrite and TBARS with SAME may suggest a role of SAME in controlling various pathological conditions, including oxidative stress [20]. Histopathologic results in the present study revealed that $\mathrm{CCl}_{4}$ induces extensive fatty change, blood vessel congestion, cellular hypertrophy, necrotic foci, destruction of the lobular architecture, fibrosis, and nuclear degeneration in some areas, all of which were markedly diminished by induction of SAME. These data are in good agreement with the results of the serum aminotransferase activities and hepatic lipid peroxidation levels. Similar protection was evident with respect to necrosis, which is a more severe form of injury, in that it was minimized by treatment with SAME. Other studies on the protective effect of Carissa opaca extract against $\mathrm{CCl}_{4}$-induced hepatotoxicity in rats have revealed similar findings that are in agreement with the present findings [44].

\section{Conclusions}

This study evaluated the pharmacological use of SAME against $\mathrm{CCl}_{4}$ induced liver injuries. Low lipid peroxidation and increased activities of various antioxidant enzymes indicate that SAME is able to protect various pathological conditions, including oxidative stress. It is suggested, to isolate the antioxidants from SAME that could be utilized as therapeutics against the oxidative diseases.

\section{Competing interests}

The authors declare that they have no competing interests.

\section{Author details}

${ }^{1}$ Department of Biotechnology, Faculty of Biological Sciences, University of Science and Technology Bannu, Khyber Pakhtunkhwa, Pakistan. ${ }^{2}$ Department of Biochemistry, Faculty of Biological Sciences, Quaid-I-Azam University Islamabad, Islamabad, Pakistan. ${ }^{3}$ Botanical Sciences Division, Pakistan Museum of Natural History, Islamabad, Pakistan.

\section{Authors' contributions}

RAK made significant contribution to acquisition of data, analysis, drafting of the manuscript. MRK SS and NAS have made substantial contribution to conception and design, interpretation of data, drafting and revising the manuscript for intellectual content. All authors read and approved the final manuscript.

Received: 13 December 2011 Accepted: 9 July 2012

Published: 9 July 2012

\section{References}

1. Jemal A, Siegel R, Ward E: Cancer statistics. Cancer J Clin 2007, 57:43-66

2. Guven A, Guven U, Gulmez M: The effect of kefir on the activities of GSH, GSHPX, GST, CAT, GSH and LPO levels in carbon tetrachloride-induced mice tissue. J Vet Med 2003, 50:412-416.

3. Ozturk F, Ucar M, Ozturk IC, Vardi N, Batcioglu K: Carbon tetrachloride induced nephrotoxicity and protective effect of betaine in Sprague Dawley rats. Urology 2003, 62:353-356.

4. Khan MR, Rizvi W, Khan GN, Khan RA, Shaheen S: Carbon tetrachloride induced nephrotoxicity in rat: Protective role of Digera muricata. J Ethnopharmacol 2009, 122:91-99.

5. Weber LW, Boll M, Stampfl A: Hepatotoxicity and mechanism of action of haloalkanes: carbon tetrachloride as a toxicological model. $\mathrm{Cr} \operatorname{Rev}$ Toxicol 2003, 33:105-136.
6. Ogeturk M, Kus I, Colakoglu N, Zararsiz I, Ihan N, Sarsilmaz M: Caffeic acid phenyl ester protects kidney against carbon tetrachloride toxicity in rats. J Ethnopharmacol 2005, 97:273-280.

7. Szymonik-lesiuk S, Czechowska G, Stryjecka-Zimmer M, Słomka M, Madro A Celinski K, Wielosz M: Catalase, superoxide dismutase, and glutathione peroxidase activities in various rat tissues after carbon tetrachloride intoxication. J Hepato-Biliary-Pancreatic Surg 2003, 10:309-315.

8. Preethi KC, Kuttan R: Hepato and reno protective action of Calendula officinalis L. flower extract. Indian J Exp Biol 2009, 47:163-168.

9. Ichi I, Kamikawa C, Nakagawa T, Kobayashi K, Kataoka R, Nagata E, Kitamura Y, Nakazaki C, Matsura T, Kojo S: Neutral sphingomyelinase-induced ceramide accumulation by oxidative stress during carbon tetrachloride intoxication. Toxicology 2009, 261:33-40.

10. Jia X, Han C, Chen J: Effect of tea on preneoplastic lesions and cell cycle regulators in rat liver. Cancer Epidemiol Biomark Prevent 2002, 11:1663-1667.

11. Khanna AK, Ansari MA, Kumar M, Khanna A: Correlation between AgNOR quantity in needle biopsy specimens of prostatic adenocarcinomas: correlation with proliferation state, Gleason score, clinical stage, and DNA content. Clin Mol Pathol 2003, 49:209-213.

12. Fahmy SR, Hamdi SAH, Abdel-Salam HA: Curative effect of dietary freshwater and marine crustacean extracts on carbon tetrachlorideinduced nephrotoxicity. Aust J Basic Appl Sci 2009, 3:2118-2129.

13. Van Gijssel HE, Maassen CB, Mulder GJ, Meerman JH: $P^{53}$ Protein expression by hepatocarcinogens in the rat liver and its potential role in mitoinhibition of normal hepatocytes as a mechanism of hepatic tumor promotion. Carcinogenesis 1997, 18:1027-1032.

14. Afolayan AJ, Gimo FO: Nutritional quality of some wild leafy vegetables in South Africa. Int J Food Sci Nutr 2009, 60:424-431.

15. Guil-Guerrero JS, Gimenez-Gimenez A, Rodrguez-Garc I, Torija-Isasa ME: Nutritional composition of Sonchus species (S. asper L., S. oleraceus L. and S. tenerrimus L.). J Sci Food Agric 1998, 76:628-632.

16. El-Zalabani SM, Mahmoud II, Ahmed FI, Shehab NG: Protein, carbohydrate, mineral and vitamin contents of Sonchus oleraceus L. growing in Egypt, Al-Azhar. J Pharm Sci 1999, 23:46-54.

17. Middleton E, Kandaswami C, Theoharides TC: The effects of plant flavonoids on mammalian cells: Implications for inflammation, heart disease and cancer. Pharmacol Rev 2000, 52:673-751.

18. Manach C, Mazur A, Scalbert A: Polyphenols and prevention of cardiovascular diseases. Curr Opinion Lipid 2005, 16:77-84.

19. Helal AM, Nakamura N, El-Askary H, Hattori M: Sesquiterpene lactone glucosides from Sonchus asper. Phytochemistry 2000, 53:473-477.

20. Alpinar K, Ozyurek M, Kolak U, Guclu K, Aras C, Altun M, Celik SE, Berker KI, Bektasoglu B, Apak R: Antioxidant capacities of some food plants wildly grown in Ayvalik of Turkey. Food Sci Tech Res 2009, 15:59-64.

21. Koche DK, Shirsat RP, Imran S, Nafees M, Zingare AK, Donode KA: Ethnomedicinal Survey of Nageria Wild Life Sanctuary, District Gondia (M.S.). India- Part II. Ethnobot Leaflets 2008, 12:532-537.

22. Zabihullah Q, Rashid A, Akhter N: Ethanobotnical survey in Kot Manzary Baba valley malakand agency, Pakistan. Pakistan J Plant Sci 2006, 12:115-121.

23. Kareru PG, Kenji GM, Gachanja AN, Keriko JM, Mungai G: Traditional medicine among the Embu and Mbeere peoples of Kenya. Afr J Trad Compl Alter Med 2007, 4:75-86.

24. Lowry OH, Rosenberg NJ, Farr AL, Randall RJ: Protein measurement with Folin Phenol reagent. J Biol Chem 1974, 193:265-275.

25. Chance B, Maehly AC: Assay of catalase and peroxidases. Methods Enzymol $1955,11: 764-775$.

26. Kakkar P, Das B, Viswanathan PN: A modified spectrophotometric assay of superoxide dimutase. Indian J Biochem Biophys 1984, 21:130-132.

27. Habig WH, Pabst MJ, Jakoby WB: Glutathione-S-transferases: the first enzymatic step in mercapturic acid formation. J Biol Chem 1974, 249:7130-7139.

28. Carlberg I, Mannervik EB: Glutathione level in rat brain. J Biol Chem 1975, 250:4475-4480.

29. Mohandas J, Marshal JJ, Duggin GG, Horvath JS, Tiller DJ: Differential distribution of glutathione and glutathione-related enzymes in rabbit kidney. Possible implications in analgesic nephropathy. Biochem Pharmacol 1984, 33:1801-1807.

30. Jollow DJ, Mitchell JR, Zampaglione N, Gillete JR: Bromobenzene induced liver necrosis. Protective role of glutathione and evidence for 3,4- 
bromobenzene oxide as a hepatotoxic metabolite. Pharmacology 1974, 11:151-169.

31. Iqbal M, Sharma SD, Zadeh HR, Hasan N, Abdulla M, Athar M: Glutathione metabolizing enzymes and oxidative stress in ferric nitrilotriacetate (Fe-NTA) mediated hepatic injury. Redox Rep 1996, 2:385-391.

32. Wu B, Ootani A, Iwakiri R, Sakata Y, Fujise T, Amemori S, Yokoyama F, Tsunada S, Fujimoto KL: T cell deficiency leads to liver carcinogenesis in Azoxymethane-treated rats. Exp Biol Med 2005, 231:91-98.

33. Trere D, Zilbering A, Dittus D, Kim P, Ginsberg PC, Daskal I: AgNOR quantity in needle biopsy specimens of prostatic adenocarcinomas: correlation with proliferation state, Gleason score, clinical stage, and DNA content. Clin Mol Pathol 1996, 49:209-213.

34. Toklu HZ, Tunali AT, Velioglu-Ogunc A, Ercan F, Gedik N, Keyer-Uysal M, Sener G: Silymarin, the antioxidant component of Silybum marianum, prevents sepsis-induced acute lung and brain injury. J Surg Res 2008, 145:214-222.

35. Recknagel RO, Glende EA, Dolak JA, Waller RZ: Mechanisms of carbon tetrachloride toxicity. Pharmacol Therap 1989, 43:139-154.

36. Lin HM, Tseng HC, Wang CJ, Lin JJ, Lo CW, Chou FP: Hepatoprotective effects of Solanum nigrum Linn. Extract against $\mathrm{CCl}_{4}$-induced oxidative damage in rats. Chem Biol Inter 2008, 171:283-293.

37. Guo Y, Zhou X, Fan W, Qu G: Protective action of Sonchus arvensis L. against hepatic injury. Shenyang Yaoxueyuan Xebio 1994, 11:278-281.

38. Khan RA, Khan MR, Sahreen S: Prevention of $\mathrm{CCl}_{4}$-induced nephrotoxicity with Sonchus asper in rat. Food Chem Toxicol 2010, 122:91-99.

39. Kamalakkannan N, Rukkumani R, Aruna K, Varma PS, Viswanathan P, Menon VP: Protective effect of $\mathrm{N}$-acetyl cysteine in carbon tetrachloride-induced hepatotoxicity in rats. Iranian J Pharmacol Therap 2005, 4:118-123.

40. Feng J, Funk WD, Wang SS, Weinrich SL, Avilion AA, Chiu CP: The RNA component of human telomerase. Science 1995, 269:1236-1241.

41. Singh N, Kamath V, Narasimhamurthy K, Rajini PS: Protective effects of potato peel extract against carbon tetrachloride-induced liver injury in rats. J Environ Toxicol Pharmacol 2008, 6:242-246.

42. Khan RA, Khan MR, Sahreen S: Protective effect of Sonchus asper extracts against experimentally-induced lung injuries in rats: a novel study. Exp Toxicol Pathol, . http://dx.doi.org/10.1016/j.bbr.2011.03.031.

43. Ohkawa $\mathrm{H}$, Ohishi $\mathrm{N}$, Yogi $\mathrm{K}$ : Assay for lipid peroxidation in animal tissues by thiobarbituric acid reaction. Ann Biochem 1989, 95:351-358.

44. Sahreen S, Khan MR, Khan RA: Hepatoprotective effects of methanol extract of Carissa opaca leaves on $\mathrm{CCl}_{4}$-induced damage in rat. $\mathrm{BMC}$ Comp Alter Med 2011, 11:48.

doi:10.1186/1472-6882-12-90

Cite this article as: Khan et al.: Hepatoprotective activity of Sonchus asper against carbon tetrachloride-induced injuries in male rats: a randomized controlled trial. BMC Complementary and Alternative Medicine 2012 12:90

\section{Submit your next manuscript to BioMed Central and take full advantage of:}

- Convenient online submission

- Thorough peer review

- No space constraints or color figure charges

- Immediate publication on acceptance

- Inclusion in PubMed, CAS, Scopus and Google Scholar

- Research which is freely available for redistribution 